\title{
Structural Effects on the Climatic Architecture
}

\author{
Sania Sami \\ Department of Architecture and Urban Planning, \\ Science and Research Branch-Qeshm, Islamic Azad University, Qeshm Island, Iran. \\ Roughayeh Rezanejad Zanjany \\ Department of Architecture and Urban Planning, \\ Yadegar Imam, Shahr-e-Rey, Islamic Azad University, Tehran, Iran.
}

\begin{abstract}
climatic architecture, like Islamic architecture and any other traditional architecture, is related to worldview. Traditional Iranian architecture, in a particular way, is an allegory of the universe of existence and human, in its cosmic form. Islamic civilization is a prominent example of a traditional civilization, in which there is the presence of certain extreme principles that shadow the civilization over time and space. Islamic art is nothing more than the reflection of soul in this mundane world. From this perspective, it seems that the definition of sociologists from religious art and Islamic art is different from the sociological definition of art in general [1]. The relationship between architecture and environmental features is important not only for native architects, but also for non-native architects who have grown in a different cultural context. Exploring such an interactive process is full of unique and tricky perceptions, both for non-native architects and for audiences, employers, and analysts. One of the doubts is that in today's world, where the boundaries of countries have lost their credibility in the eyes of architects, and they are always looking for new opportunities in new environments, does this recommendation that the work of architecture should interact with the cultural platform make any sense? The new ideas of globalization, which respect regional attitudes, respond positively to the above question, which ultimately suggests that today, political, social and cultural decisions are made in different parts of the world based on a global-indigenous attitude [2].
\end{abstract}

Keywords: Regionalism, Sustainable architecture, Ecosystems, Possibility of location, Contextualism, Regionalism, Physical identity

\section{INTRODUCTION}

Climatization is an analytical perspective that pritorizes emphasizes on maintaining specific ethnic and traditional features of the region for the specific identity of the region versus universal characteristics. The current paper studies the background and evolution of regionalism theory in architecture by analyzing the views of experts in explaining the dominant approaches in this field. This is a qualitative, analytical-interpretative method paper based on documentary method. The results of the studies indicate that regionalism theory has shifted from nativism with emphasis on physical perceptions, and the style, form and aesthetics of the region to modern approaches focusing on social, cultural, ecosystem and human communication, in search of modifying past bias and limitations, as well as strengthening the interactive approach and the use of global advantages. Accordingly, emphasis on people's participation, and design focusing on local needs and capabilities for sustainable development, a bottom-up approach in the design instead of the centralized topbottom method, attention to the real realities of mankind and cultural, social and normative values in order to resist the same artifact environment, to strengthen the sense of place, creative protection instead of retrospective look, critical regionalism and inter-regional 
regionalism are of the dominant regionalism strategies and discourses in the form of physical, ecological and semantic approaches[3].

The centrality of the issue of the relationship between the place architecture and the establishment of thought in a critical position relative to the forms and spaces that result from the communities created by displacements and global communities leads to a critical reexamination of native culture by the application of modernist strategies. Also, what's seen as a confirmation of native environments from the point of view of critical regionalism is related to the issue of global rising environmental crises. In the explanation of the term regionalism, many concepts, both in the field of definition and in the field of application, are often derived from the concepts that are apparent with the main purpose of the word regionalism, differences, and in some cases contradictions. This challenge is due to the widespread use of regionalism. Also, because regionalism, in the heart of its definitions, has an interactive bipolar word such as tradition-modernity, global-indigenous, and past-future; thus, if the balance between the two terms is eliminated, certain approaches replace the regionalism approach, some are as follows:

The regional attribute is the essential property of any architecture. Since all buildings are part of the fixed place, they cannot be the same in all places, but must include specific features of a given location. From ancient times, this feature is known as the mood, and historic buildings, although in general style, usually have a certain local mood. So, architecture helps man to find himself in the mood of a place, and the place also gives him a sense of belonging and safety [4].

\section{PHYSICAL IDENTITY IN NATIVE AFFAIRS}

Concepts of native and traditional architecture are a metaphorical expression of active coordination with climatic conditions that focus on ethnic characteristics, attention to the principles of traditional architecture, the use of indigenous details, materials and decorations inspired by specific regional concepts, and in a point resulted in sharing in regionalism and architectural experiences in the field of foreigners. The analysis of the results of this research shows that the metaphorical expression of native forms as modern technology is the most important practical approach of architects in the field of alienation to interact between global identity and regional identity. Also, successful examples emphasize the process of architectural interaction and design context, and create the necessary social infrastructures for logical linkages with the characteristics of the world today [5].

Physical identity means features and qualities that distinguish the body of the city from other issues, and reveal its similarity to the insiders. These features must be such that the body of the city, while preserving the temporal continuity, is also evolving, and ultimately leads to the emergence of a whole. Conceptual identity is synonymous with terms of personality and sense of place. Hence, the criteria for assessing physical identity are as follows:

1. Distinction/Similarity means the distinction of foreigner and similarity with the self.

2. Continuity/evolving means the connection with the past and the lack of discontinuity (continuity of meaning and values of the self) while innovating and creativity according to the circumstances of time (resisting the features of the self but not staying the same).

3. Unity/Pluralism means the connection between heterogeneous and even contradictory components in such a way as to bring together the whole.

Theories of contextism and regionalism are the theoretical basis of interpretation of the above criteria in the areas of architecture and urban design [6]. 


\section{Regionalism and the climate indignation}

There are a set of self-conscious theories that differentiate regionalism and native-ism, responding to indigenous conditions by force and not on choice. Native-ism, often defined by the unconscious, refers to the characteristics of the canvas, which inhabitants adapt to their architecture, not to regionalism, but to the accident. But regionalism is a voluntary and selfconscious activity chosen by various agents (planners, architects, or policymakers) from among available options [7] (Canizaro, 2007, 20).

Ozkan (1985) and (2007) refer to a comprehensive definition of native-ism to explain the difference between regionalism and native-ism. Referring to Rudolfsky's (1964) and Oliver (1969) and (1977) studies, he recognizes native peoples with two defensive and interpretative perspectives, and believes that although both groups, their ideals, present a new and contemporary representation of forms and spatial organization of native (local) they are different in the face of the two concepts of "technology" and "community." Conservative indigenous people, such as Hassan Fathi, have paid special attention to the community and they care about restoring native traditions in building. Housing is the most commonly used application in this range of architects. He defines the nativism descriptive version as neonativism as a vision that seeks to give new life to the native heritage to achieve new and contemporary functions. This method has the most application in the development of the tourism industry. Neo-nativism, to achieve the calmness of today, the ease of construction and maintenance of the building, uses technologies that are largely unprecedent in the region [8].

Ozkan takes the major difference between regionalism and indigenous peoples on the scale of their influence. In his opinion, their attitudes are limited when native-ism or neo-nativism extends from the scale of small buildings to large urban buildings. In other words, native-ism is one aspect and, in fact, is a limited aspect of regionalism that incorporates a limited variety of varieties that are prevalent in native culture [9].

The semantic interference between regionalism and native-ism arises when the industrialization and the emergence of new technologies, along with new methods of life, challenge human societies. Rudolf (1985), with this notion, uses regionalism instead of nativeism. He considers industrialization a constraint for regionalism. In his opinion, the ease of travel and communication are limiting factor given regionalism. The increasing cost of traditional materials and their related skills is another limitation. Regardless of wood (the materials many villages in the world made by) to the benefit of fire-retardant materials is a major architectural problem that rarely finds a solution [10]. He also argued that "some buildings are more evident than the other in the region" and introduce types of buildings that must have regional features, such as the house, and on the contrary, those that are hardly regionalized, such as the airport and or modern technical services [11]. Thus, he limits the scale of regionalism to buildings that encompass certain user-specific behavior patterns and surround the cultural aspects of their lives.

The absence of a distinction between the meaning of regionalism and native-ism limits the scale of regionalism's effect. Some believe that regionalism in the present conditions, namely the development of global media, the ease of travel and communication, economic growth, the standardization of elements and building systems, the increase in the costs of traditional skills and materials, and, ultimately, the urgency of the social conditions of humans and the complexity of legal requirements have become distant from its reality and have become a fantasy [12] (Boussora, 2007, 127). This theory believes that regionalism is limited to normal perceptions of historical and traditional elements, which today is unnecessary due to changing people's needs and patterns of behavior. 
What explains the crucial difference between regionalism and native-ism is that regionalism adopts past architectural forms by responding to today's genuine needs, and in particular functional needs [13]. Mumford considers regionalism to be the realization of the real human needs in relation to land, soil, climate, working conditions and the hidden customs of neighboring countries, and believes that this is much harder than the adaptation of the past decoration. In his opinion, close adaptation to the environment and a conscious effort to make optimal use of regional resources and opportunities are an expression of regionalism [14] (Mumford, 2007, 98). According to Mumford, regionalism does not involve the use of all material or copying simple forms of construction that our ancestors used. Regional forms are those that are associated with real life situations and are more successful in fostering people's feelings about their home and environment. They are not exclusively made of soil but represent the existing cultural conditions of the region [9].

In contrast, native-ism views past architectural forms from the stylistic regeneration point of view and prescribes a kind of emotional historicism in the face of past architectural traditions [15].

\section{Architectural Ethnographic Structure}

Regionalism is different from Ethnic-ism. Although both share the two geographic terms. Ethnic-ism, in the beginning, was functional in the 19th and early 20th centuries, and from a cultural point of view, negative perceptions were made about it, and pointed to things that were limited and natural. Ethnic works differed from region-specific works, as these works, due to the distance from the cultural center, were subject to limitations, especially in terms of standards. Whereas, on the contrary, regionalism, by virtue of its resistance to the identical values and tastes developed from the administrative centers, activated local values, and the regional look, with its native look [7] (Camizaro, 2007, 21).

Pointing out that architecture has always been heavily influenced by past architectural experiences, Newcomb (2007) has pointed to the direct perception of past architectural styles as a diversionary subject, which has been added to the definition of regionalism. This method is used by the eth-no-architecture, which has previously looked at regrettable past. He takes the main difference between regionalism and ethnicity in their view of the future. Ethnic-ism seeks to revive the characteristics of the past social life in the form of architecture, while regionalism looks at a different and changing future. Ethnic-ism removes the architect from the scene and believes in the spontaneous creation of architecture, while in regionalism, the architect has an important role in interacting between the design and the location of the generations [16].

\section{Regionalism and nationalism}

The specific cultural and climatic characteristics, although are taken into account as the two views of regionalization and nationalism, the different motives of these two approaches, in the face of specific regional characteristics, are the basis of the difference between these two attitudes. Berry (2007) defines nationalism as "pride- based regionalism", contrary to tolerance-based regionalism. In nationalism, myths, attributes and abstractions of a place are evaluated separately from the place and become national symbols. Achieving a sense of pride is a feature that is developed by the consolidation of the ruling class to achieve national unity [17].

Harris (2007) defines nationalism as the first type of regionalization by defining two types of regionalism, regionalism, or monopoly against liberalism. In his view, limitations of zonality are rooted in distinctions and limitations, and are less indicative of dialectical interaction in clarifying ideas. Such regionalism is an anti-international and anti-progress system. This is 
even though freedom regionalism, in addition to emphasizing the existence of characteristics and differences, is positive to the world of culture. According to Harris, the difference between regionalism and nationalism is that the expression of regionalism is based on the expression of freedom. This expression is a picture of the benefits of the new realm, new ways of life, new forms of construction, and new forms of harmony. The human being image uncovers the world in terms of architecture and understands them more than ever that is the picture of liberation, carefreeness and diversity. Architecture, when it depicts diversity, freedom and expansion, can achieve the best regionalism, and the nationalist expression is a statement of unity, consolidation and anti-diversity, because the word "nation" means united peoples. The goal of nationalist architecture is, more, the unity of the people as their citizens.

Since the nation is essentially a symbol, nationalist architecture must create an image of the qualities that are recognized as the symbol of nationality [18].

Mumford, referring to regionalism developments at the beginning of this century, sees it as a challenge to nationalism and the regionalism of governments. The suppression of regional features in the direction of national unity, so systematically, by modern governments, is the result of this confrontation. According to him, regional groups led to the emergence of a ghost of national disruption, which was fought with them through the educational system and propaganda. He believes that such conflicts are since the realities of the region and societies do not coincide with the boundaries and ideological patterns of the national government. Mumford regards regionalism as a cultural and political doctrine as a signifying the interregional framework that ultimately leads to global culture. Thus, regionalism, not the emotional and imaginary past, which belongs to the realist future, is a future that will undermine the ineradicable realm of public life, and will devolve upon the ruins of obsessive mythology and the inefficient mechanisms of the mighty state [14].

Despite the views, which counts regionalism and nationalism as opposed to each other, Colucahan considers the greatest factor in increasing the effectiveness of regionalism to be the increase in the strength of central national states. He defines the relation between regionalism and nationalism in two ways: one that sees people who have lost their cultural identities, who use the term ethnicity to justify the claim of unity or independence, and the latter is the national states, making their own ethnic traditions as they wish [19].

Regionalism is beyond design based on adaptation or reliance on resources. Regionalization fosters communication with the locality and responds to the needs of native life. Not in conflict with global considerations and preferences, but also to seek out the best of them. The promise of regionalism in architecture means that we understand the realities and diversity of our native places with ease and with a critical look. Regionalism has the capability to put us in continuity with our individual and social history. Ultimately, regionalism provides opportunities for common goals that are perceived here in terms of ecological, economic, and social perception [7] (Canizaro, 2007, 13).

\section{Effects of Tradition and Modernity}

The contradiction between tradition and modernity is linked to the challenge of the need for cultural continuity and the passion for progress and innovation. For a sociologist such as Anthony Giddens, tradition means a tool for coordinating time and space that places every specific activity or experience in continuity with the past, present, and future [7] (Canizaro, $2007,23)$. Traditions include cultural and visual knowledge of the continual changes of culture. In the best of circumstances, the dynamic tradition provides a context in which growth and change can be measured. In the worst case, tradition is constant and non-existent, which is 
either a factor in disrupting growth or is represented by the expression of cultural differences. Canizaro sees modernity as a state of social life in which "modernization" is the driving force. Newness often needs to undermine traditions, and it is a continuous movement for the benefits of innovation and progress. However, expelling in the cultural structures (traditions) of society includes negative consequences [11] (Ibid).

In his article entitled "The tradition and modernity of the feasibility of regionalism architecture in postmodern societies,"Palmasma (2007) explains his concern for the spread of modernism: "The modern movement, based on technology and reason and the building of economic constructions, with the slogan of machines for life, has damaged our sense of day and identity, standard buildings have increased our alienation, we have simply lost our faith in utopia. Today in our culture, the tensions caused by industrial technology, combined with nonlocation, widespread communication and unity of lifestyle have minimized diversity. What is possible for existence of culture and regional architecture, while two billion people, all watching a football game on television, similarly [20]. (Pallasman, 2007, 129).

What is to be mentioned in the above is a concern about the approach to uniformization and internationalization of architecture. Ozkan (2007), despite the belief that modernity, along with its subcategories, international attitudes, has led to the emergence of certain architectural views and values that have been rejecting all the monuments in the last 60 years, which emphasize the distinction between modernization and the international style points to the interaction between regionalism and modernism. In his opinion, what was rejected by many regionalist architects was not modernism, but globalization. Modernism tended to emphasize the quality of building materials, display structures and match the form with function. These abstract demands were not inconsistent with what regional architects sought [8].

At the center of the contradictions above, regionalism faces two approaches. Historical regionalism, which displays the conservative tendencies of tradition, and, conversely, regionalist modernism and critical regionalism, which construct newness based on measures derived from tradition and regional culture.

\section{Theoretical and typo-logical typology of regionalization approach}

Regionalism is a flexible approach that offers different recommendations in each period, according to the circumstances. Flexibility, by adding complementary vocabularies to the term regionalization, makes practical expression and continuity of life possible in the present situation. In this way, the term regionalism finds elegance beyond its verbal meaning and allows for the adoption of various purposes (Shayan \& Kamatiya, 2008, 14). Cole Cohen (2007) explains the above interpretation in the word "fluidity", as one of the features of regionalism. In her opinion, regionalism, like any other school of thought, must be so fluid that it ends up with fruitful social results, despite the inherent contradictions. she states that regionalism must constantly adapt itself to changing conditions and expose itself to each culture. By this definition, Cole Cohen concludes that such an interpretation of regionalism cannot be regarded as a theory, but it may also seem like an approach or perspective [21].

The fluidity and flexibility available in the definitions of regionalism has led various theorists to identify different types of regionalism. However, in all existing definitions, commons such as "paying attention to indigenous and regional characteristics," "responding to genuine needs rooted in culture and traditions," "attention to the past based on choice and not coercion," and "attention to today's needs and conditions" exist, but there are distinct differences between them in terms of practical arrangements and mechanisms for confronting the place and the region. These differences are due to the different influences that regionalism accepts from its 
theories and views. Dominance of dominant architectural ideas such as classical-ism, modernism, international style, postmodernism, and theories governing human relationships such as globalization, and multi regionalism in recent years have raised regionalism from different aspects in architecture literature.

The description of regionalism and recognition of the theoretical grounds and their practical procedures can redefine the contradictions and ambiguities in explaining the regionalization approach. What matters at any time is how has been the link between architecture and cultural features. Categorizing existing approaches can make future predictions relevant to changing variables governing global thought. The answer to the question of how today regionalism can respond to the concerns and identity of peoples facing a world without borders is the timebased analysis of existing attitudes.

Several phrases derived from such interactions indicate the potential dynamics of regionalism. The basis of this dynamics is hidden in the dynamic interpretations of the word region. 
*Table 1: Comparison of the regional spatial- physical structure

\begin{tabular}{|c|c|c|c|c|c|c|c|}
\hline & title & Hi-Tec & $\begin{array}{ll}\begin{array}{l}\text { Plan } \\
\text { picture }\end{array} & \& \\
\end{array}$ & Green architecture & $\begin{array}{ll}\text { Plan } & \& \\
\text { architecture } & \\
\end{array}$ & difference & similarity \\
\hline 1 & $\begin{array}{l}\text { Use of } \\
\text { technology } \\
\text { resources }\end{array}$ & $\begin{array}{l}\text { Using: } \\
\text { 1. prefabricated } \\
\text { components } \\
\text { 2. Glass walls } \\
\text { 3. Steel framework }\end{array}$ & $\begin{array}{l}\text { Norman } \\
\text { Foster }\end{array}$ & $\begin{array}{l}\text { 1. Solar panels 2- Use } \\
\text { of materials in nature } \\
\text { 3. Use of green roof }\end{array}$ & & $\begin{array}{l}\text { 1. Pay attention to the } \\
\text { fan and structures in } \\
\text { the single doors } \\
\text { 2. Prevent energy loss } \\
\text { in green architecture }\end{array}$ & $\begin{array}{l}\text { 1- Attention to } \\
\text { human need } 2 . \\
\text { Make comfort } 3 \text { - } \\
\text { Create the right } \\
\text { view }\end{array}$ \\
\hline 2 & $\begin{array}{l}\text { Design } \\
\text { Principles }\end{array}$ & $\begin{array}{l}\text { 1. Positive vision and } \\
\text { nose to science and } \\
\text { scientific advancement } 2 \text {. } \\
\text { Technology presentation } \\
\text { as a new age extract 3- } \\
\text { Display the build process } \\
\text { 4. Transparency and } \\
\text { movement of the building } \\
\text { 5- Display the structure } \\
\text { of the building in the } \\
\text { facade 6- Use of color }\end{array}$ & $\begin{array}{l}\text { Rastatt } \\
\text { Center } \\
\text { Richard } \\
\text { Rogers }\end{array}$ & $\begin{array}{l}\text { 1- Protection of } \\
\text { energy } 2 \text { - Working } \\
\text { with the climate } 3 \text {. } \\
\text { Reduce the use of } \\
\text { new resources } 4 \text {. } \\
\text { Respect for users } 5 \text {. } \\
\text { Respect for the site } 6 \text {. } \\
\text { Holistic-ism }\end{array}$ & $\begin{array}{l}\text { The suspended } \\
\text { tower of the AED } \\
\text { in China }\end{array}$ & $\begin{array}{l}\text { 1- Single-construction } \\
\text { doors are constructed } \\
\text { using building } \\
\text { materials. } \\
2 \text { - In green } \\
\text { architecture, using } \\
\text { motion in nature and } \\
\text { being identical with } \\
\text { nature. }\end{array}$ & $\begin{array}{l}\text { 1- Lightweight } \\
\text { construction 2- } \\
\text { Pay attention to } \\
\text { implementation } \\
\text { details }\end{array}$ \\
\hline 3 & history & $\begin{array}{l}\text { 1- Login from } 100 \text { years } \\
\text { ago } \\
\text { 2- The first creation in } \\
\text { Paris 3- In } 18704 \text { - The } \\
\text { Tallest Steel Structural } \\
\text { Tower (Eiffel) }\end{array}$ & Eiffel tower & $\begin{array}{l}\text { 1- The first period } \\
\text { since } 1970 \\
\text { 2. It coincided with } \\
\text { modern times. } \\
\text { 3. In America and } \\
\text { Europe } \\
\text { 4. The First City } \\
\text { Without Carbon and } \\
\text { Waste }\end{array}$ & Dubai Twin Tower & $\begin{array}{l}\text { 1- In the type of } \\
\text { structure Bright and } \\
\text { light } 7 . \text { Structures and } \\
\text { structures as } \\
\text { decorations } 8 \text {. Use of } \\
\text { light stretching } \\
\text { components }\end{array}$ & $\begin{array}{l}\text { 1. Both are } \\
\text { contemporary } 2 . \\
\text { Both have an } \\
\text { upgrade }\end{array}$ \\
\hline 4 & $\begin{array}{l}\text { How to } \\
\text { put on the } \\
\text { site }\end{array}$ & $\begin{array}{l}\text { 1- Due to windsurf for } \\
\text { bracing 2- Due to the } \\
\text { distorted sound 3- } \\
\text { Rotation according to } \\
\text { urban construction }\end{array}$ & $\begin{array}{l}\text { Amazon } \\
\text { domes }\end{array}$ & $\begin{array}{l}\text { 1. Each building } \\
\text { should touch the } \\
\text { earth in a calm and } \\
\text { light manner. } \\
\text { 2- According to the } \\
\text { angle of the sun } \\
\text { 3- According to the } \\
\text { direction of wind } \\
\text { blowing } \\
\text { 4- Due to the } \\
\text { presence of water }\end{array}$ & & $\begin{array}{l}1 \text { - In green } \\
\text { architecture, it is } \\
\text { necessary to match the } \\
\text { surrounding } \\
\text { environment. }\end{array}$ & $\begin{array}{l}\text { 1- Both are } \\
\text { designed } \\
\text { according to the } \\
\text { angle of } \\
\text { incidence and } \\
\text { wind direction }\end{array}$ \\
\hline 5 & $\begin{array}{l}\text { The } \\
\text { purpose of } \\
\text { creation }\end{array}$ & $\begin{array}{l}\text { 1. Response to the } \\
\text { expansion of modern } \\
\text { architecture's frustration } \\
\text { 2. Superior technology } \\
\text { architecture } \\
\text { 3. Development and } \\
\text { progress of the world }\end{array}$ & 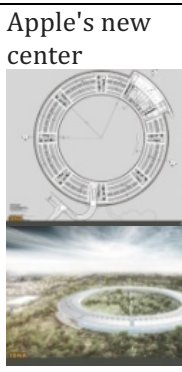 & $\begin{array}{l}\text { 1- Use of durable } \\
\text { nature } 2 \text {. Source } \\
\text { material of quality } \\
\text { and perpetuity } 3 . \\
\text { Rely on natural } \\
\text { forces like the sun } \\
\text { and wind to produce } \\
\text { electricity and light } 4 . \\
\text { Integration with } \\
\text { nature }\end{array}$ & $\begin{array}{l}\text { French Green } \\
\text { Tower }\end{array}$ & $\begin{array}{l}\text { 1- In nature's green } \\
\text { architecture, the first } \\
\text { letter says 2- Superior } \\
\text { in single technology }\end{array}$ & 1-Move on site \\
\hline 6 & $\begin{array}{l}\text { Famous } \\
\text { architects }\end{array}$ & $\begin{array}{l}\text { 1-Richard Rogers = } \\
\text { London Millennium } \\
\text { Dome }\end{array}$ & & $\begin{array}{l}\text { 1- Charles David } \\
\text { Killing = Zeb's house } \\
\text { in Nurse }\end{array}$ & & $\begin{array}{l}\text { 1- Round and rounded } \\
\text { plan } 2 \text {. A rectangular } \\
\text { plan }\end{array}$ & $\begin{array}{l}1 \text { - The beauty of } \\
\text { art in making }\end{array}$ \\
\hline 7 & $\begin{array}{l}\text { How to } \\
\text { implement } \\
\text { in } \\
\text { architectu } \\
\text { re }\end{array}$ & $\begin{array}{l}\text { 1- Tall buildings with } \\
\text { simple glass and glass 2- } \\
\text { Emphasis on the } \\
\text { grandeur and strength of } \\
\text { the steel framework }\end{array}$ & & $\begin{array}{l}\text { 1- Being level with } \\
\text { nature 2- Mostly built } \\
\text { in a villa }\end{array}$ & $\begin{array}{l}\text { Kindergarten } \\
\text { green scallop }\end{array}$ & 1-Altityte balance & $\begin{array}{l}\text { 1- Structural } \\
\text { and building } \\
\text { tightness }\end{array}$ \\
\hline 8 & $\begin{array}{l}\text { Login in } \\
\text { Iran }\end{array}$ & $\begin{array}{l}\text { 1- Entrance to the } \\
\text { Pahlavi Period }\end{array}$ & & 1- From 57-47 & Does not have & & \\
\hline
\end{tabular}




\begin{tabular}{|c|c|c|c|c|c|c|c|}
\hline 9 & buildings & $\begin{array}{l}\text { 1- Stadium of Farah Abad } \\
\text { (Takhty 2- Cultural } \\
\text { Center for Sound and } \\
\text { Television 3- } \\
\text { Kermanshah Regional } \\
\text { Museum }\end{array}$ & $\begin{array}{l}\text { Stadium of } \\
\text { Farah Abad } \\
\text { (Takhty) }\end{array}$ & $\begin{array}{l}\text { 1- Isfahan Master } \\
\text { Plan } \\
\text { 2- The urban area of } \\
\text { Isfahan } \\
\text { 3- Isfahan Town } \\
\text { Development Center }\end{array}$ & $\begin{array}{l}\text { Urban area of } \\
\text { Isfahan }\end{array}$ & $\begin{array}{l}\text { 1- In the modern era of } \\
\text { Pahlavi }\end{array}$ & $\begin{array}{l}\text { 1. Stable and } \\
\text { solid foundation }\end{array}$ \\
\hline
\end{tabular}

\section{CONCLUSION}

Regionalism is one of the architectural approaches that interacts with culture and cultural grounds, and emphasizes the importance of cultural-climatic characteristics. These features ultimately give the architecture a "mood" and enhance the sense of place in space. After the advent of modernism, regionalism posed many challenges regarding the interaction or opposition of modern architecture and cultural identities of the region to modern architectural theories, which resulted in the transformation of the attitude to regionalism in terms of lexical terms such as modern regionalism as well as critical regionalism. Regionalization is explained by defining the key vocabulary of this domain, and by using this term, the meaning of regionalism becomes clearer.

A region is initially a broad area with borders that are characterized by cultural and natural criteria. At the end of the cultural range that is evident in the root of the word, control with the program or enjoying the realm of power is raised as a criterion. On the other hand, the region is characterized by natural elements such as physical forms, vegetation, natural disasters, and animals. Among the above criteria, the most common ones are climate and land issues, and cultural contexts such as specific lifestyles, land use patterns, economic organization, language market, and the ways in which dialogue and apparent practices used in building and architectural styles [22].

\section{References:}

Ahmadi J, Feizi M, Ahmadi M (Summer of 2016) Study of the position and importance of undergraduate architecture degree courses, City Identity magazine, No. 26 Scientific / Research / ISC, 14 pages, 85-98.

Taheri J, Nadimi H, The hidden dimension in Islamic architecture of Iran, Journal of Soil Science and Research, Sofeh, Volume 24, Issue 2, 21 pages, 5-24). http://sofeh.sbu.ac.ir

Nasr H (2013) Man and nature (spiritual crisis of modern man), Office of the Publishing of Islamic Culture, pp. 196.

Shultz PA, Kamal RN, Daniels AH, DiGiovanni CW, Akelman E (2015) International health electives in orthopaedic surgery residency training, J Bone Joint Surg Am, 97, pp. e15.

Radisic M, Park H, Gerecht S, Cannizzaro C, Langer R, Vunjak-Novakovic G (2007) Biomimetic approach to cardiac tissue engineering. Philosophical Transactions of the Royal Society of London B: Biological Sciences, 362, pp. 1357-1368.

Rodriguez MA, Ricart JE, Sanchez P (2002) Sustainable development and the sustainability of competitive advantage: A dynamic and sustainable view of the firm, Creativity and Innovation Management, 11, pp. 135-146.

Cannizzaro G, Leone M, Esposito M (2007) Immediate functional loading of implants placed with flapless surgery in the edentulous maxilla: 1-year follow-up of a single cohort study, International Journal of Oral \& Maxillofacial Implants, 22.

Bourne D, Inal G, Karatas-Özkan M, Nicolopoulou K (2011) Towards a theoretical framework for knowledge transfer in the field of CSR and sustainability, Equality, Diversity and Inclusion: An International Journal, 30, pp. 524-538.

Palmer J, Cooper I, Van der Vorst R (1997) Mapping out fuzzy buzzwords-who sits where on sustainability and sustainable development'. Sustainable development, 5, pp. 87-93.

Jomo K (2001) Southeast Asia's industrialization: Industrial policy, capabilities and sustainability, Springer.

Hawkes J (2001) The fourth pillar of sustainability: Culture's essential role in public planning, Common Ground. 
Korsavi S, Aliabadi M (2015) Geometry and Proportion of Conical Domes' Plans in Iran: Reviewing Case Studies, Journal of Architectural Engineering Technology.

Abrams RF, Malizia E, Wendel A, Sallis J, Millstein RA, Carlson JA, Cannuscio C, Glanz K, Samet J, Sleet DA (2012) Making healthy places: designing and building for health, well-being, and sustainability, Island Press.

Callicott JB, Mumford K (1997) Ecological sustainability as a conservation concept, Conservation biology, 11, pp. $32-40$.

Pyri A, Ismayilov F (2011) Comparative study of the relationship between soul and body in the philosophical system of Mulla Sadra and Bergson," Religious Studies, Volume 8, Issue 26, 15 pages, 103-118).

Newcomb M (2012) Sustainability as a design principle for composition: Situational creativity as a habit of mind, College Composition and Communication, pp. 593-615.

Berry JK, Detgado J, Khosla R, Pierce F (2003) Precision conservation for environmental sustainability, Journal of Soil and Water Conservation, 58, pp. 332-339.

Harris JM (2003) Rethinking sustainability: Power, knowledge, and institutions, University of Michigan Press.

Evans S, Spillett P, Colquhoun K (2003) SOUTH-EAST HOUSING DEVELOPMENT-THE QUEST FOR SUSTAINABILITY: WATER AND SEWERAGE NEEDS'. Water and Environment Journal, 17, pp. 257-261.

Pallasmaa J, Architecture and the Human Nature, Searching for a Sustainable Metaphor' ed.^eds., Ghost.

Colquhoun, I (2007) Design Out Crime, Routledge.

Ahmadi F, Laghaie HA, Yazdkhasti N (2013) Reconstruction and Improvement of the City's Edge of Materials in Isfahan Using Lighting (Case Study: Madi Farshadi), Volume 17, Issue 2, 15 pages, 153-168) . 